\title{
The Church Legible: George Herbert and the Externals of Worship
}

\section{Christopher Hodgkins / Calvin College}

\begin{abstract}
Christ's gospel is not a ceremonial law, as much of Moses' law was, but it is a religion to serve God, not in bondage of the figure or shadow, but in the freedom of spirit, being content only with those ceremonies which do serve to a decent order and godly discipline, and such as be apt to stir up the dull mind of man to the remembrance of his duty to God by some notable and special signification whereby he might be edified.'
\end{abstract}

Aside from Izaak Walton's Life of Herbert (1670), probably no statement has more influenced readers of The Temple (1633) than George Herbert's own lyric, "The British Church." This poem, placed exactly midway in the lyrics of "The Church," confidently celebrates the British "middle way":

I joy, deare Mother, when I view

Thy perfect lineaments and hue

Both sweet and bright...

Outlandish looks may not compare:

For all they either painted are,

Or else undrest ...

But, dearest Mother, what those miss,

The mean, thy praise and glorie is,

And long may be.

Blessed be God, whose love it was

To double-moat thee with his grace,

And none but thee. ${ }^{2}$

${ }^{1}$ [Thomas Cranmer], "Of Ceremonies, Why Some Be Abolished and Some Retained," preface to The Book of Common Prayer (1559), ed. John E. Booty (Charlottesville: University of Virginia Press, 1976), p. 19; emphasis mine.

2 George Herbert, "The Church," in The Works of George Herbert (hereafter known as Works), ed. F. E. Hutchinson, 2d ed. (Oxford: Clarendon, 1965), pp. 25-189; quote on pp. 109-10.

○ 1991 by The University of Chicago. All rights reserved. 0022-4189/91/7102-0005\$01.00 


\section{The Journal of Religion}

These lines, with their patriotic insistence on the unique blessedness of the British church, are the glass through which Herbert's poetry, and Herbert himself, have long been seen as paradigms of Anglo-Catholicism. F. E. Hutchinson says of this poem that "the via media of the Anglican Church, between Rome and Geneva, both in doctrine and in worship, is often commended by Herbert." ${ }^{3}$

Yet how could the most quoted celebrant of the via media's beauties have declared to God in "Sion" that "all this glorie, all this pomp and state,"

Did not affect thee much, was not thy aim ...

For all thy frame and fabrick is within ...

All Solomons sea of brasse and world of stone

Is not so deare to thee as one good grone?4

Do "The British Church" and "Sion" reveal the self-contradictions of a man of two minds? Or can these seemingly opposed statements, one praising and the other denigrating external "glorie," be reconciled by placement in a larger theological context? Reconciliation is indeed possible if we refer Herbert's various treatments of visible ecclesiastical structures to the idea of "notable and special signification" enunciated in the Prayer Book's prefatory statement "Of Ceremonies": that English Christians should serve God only with those outward things that "edify" by being necessary and clearly understandable. Thomas Cranmer insists that England has been reformed according to the written Word, and that its reformed church must, like that Word, be legible. The stress laid on this "legibility" by the Prayer Book and by Herbert reveals their surprising common ground with the establishment's Puritan critics-surprising, that is, if we had assumed that an appreciation of outward "decency" necessarily implied a hostility to Calvinist theology.

Such an assumption seems to have led many modern literary critics to join the ecclesiastics by placing Herbert in a "high-church" context. Some of Herbert's most influential readers-Rosemond Tuve, Louis Martz, Patrick Grant, and, more recently, Stanley Stewart - have treated him mainly as a liturgical poet, a cheerful celebrant of the established church's outward forms. ${ }^{5}$ This classification is partially understandable. Even if we

\footnotetext{
${ }^{3}$ In Works, p. 515, emphasis added. All references to Herbert's writings are to Hutchinson. Thomas Wood speaks representatively in the introduction to his pastoral anthology when he compares the "moderate Calvinist" William Perkins to Herbert, who "belonged to the school of Andrewes and Laud," which emphasized Catholic continuity over Protestant distinctiveness; see Wood's Five Pastorals (London: SPCK, 1961), p. 1. Indeed, E. C. E. Bourne, one of Laud's more recent advocates, employs "The British Church" as the epigraph to his entire book; see Bourne's The Anglicanism of William Laud (London: SPCK, 1947), p. vi.

4 "Sion," in Works, p. 106.

${ }^{5}$ Ilona Bell, "'Setting Foot into Divinity': George Herbert and the English Reformation," Modern Language Quarterly 38 (1977): 219-41. See also Rosemond Tuve, A Reading of George Herbert
} 
were completely to disregard Walton's account of Herbert as devoted ritualist and restorer of parish sanctuaries, the poems of The Temple and especially of "The Church" are permeated with references to the externals of English worship-the church's sacraments, ceremonies, architecture, vestments, liturgy, and calendar. ${ }^{6}$

However, many of Herbert's theological positions distinguish him markedly from the school of Lancelot Andrewes and William Laud. Herbert's only anti-Puritan work, Musae Responsoriae (1620), begins its attack on the Scots Calvinist Andrew Melville by agreeing with Melville's theology and choice of sacred authors. These authors include not only Ambrose, Augustine, and other ancient Fathers, but also "Martyra, Calvinum, Bezam, doctumque Bucerum," and William Whitaker, the deans of sixteenth-century reformed divinity, who proclaimed inward regeneration by the predestining divine will. ${ }^{7}$ On this common ground of conversion-oriented Protestant doctrine-most systematically expounded by Calvin and therefore "Calvinist"-Herbert engages the Puritans in controversy over "sacred ritual" and other externals.

Acknowledging such evidence, other scholars during the past decade have been more willing to address Herbert's Protestant inwardness and even to stress it in order to balance the traditional view of him as a ritualist enamored of outward forms. Indeed, Herbert's broad popularity in his own century, especially among Puritans, casts further doubt on the Laudian Walton's proprietary claims. ${ }^{8}$ Herbert's treatment of the

(Chicago: University of Chicago Press, 1952); Louis Martz, The Poetry of Meditation (New Haven, Conn.: Yale University Press, 1954); Malcolm MacKenzie Ross, Poetry and Dogma (New Brunswick, N.J.: Rutgers University Press, 1954); Patrick Grant, The Transformation of Sin (Amherst: University of Massachusetts Press, 1974); and Stanley Stewart, George Herbert (Boston: Twayne, 1986).

6 "The Church" is entered from "The Church-porch" through the portals under the Superliminare dedication. The titles of the first nine poems in "The Church" promise meditation on Christ's passion ("The Altar," “The Sacrifice," "The Thanksgiving," "The Reprisall," "The Agonie," "The Sinner," "Good Friday," "Redemption," and "Sepulchre" [Works, pp. 26-41]). Most of the last eleven lyrics deal with the eucharistic feast and three of the Four Last Things ("The Invitation," "The Banquet," "Death," “Dooms-day," "Judgement," "Heaven," and "Love" (III) [pp. 179-89]). Poems named for most of the major feast days in the Catholic tradition are interspersed in canonical order throughout the work ("Good Friday," "Easter," "Whitsunday," "Trinitie Sunday," "Sunday," "To all Angels and Saints," "Christmas," and "Lent"). Thus the nineteenth-century Anglo-Catholic John Keble generally has been seen as following both spiritually and poetically in Herbert's steps by composing The Christian Year, a cycle of devotional poems meditating on each of the rubrics in the Prayer Book. See Brian W. Martin, John Keble: Priest, Professor, and Poet (London: Croom Helm, 1976), pp. 28-29. See also Elbert N. S. Thompson, "The Temple and The Christian Year," PMLA 54 (1939): 1018-25.

${ }^{7}$ Works, p. 386, epigram 4; p. 398, epigram 33, lines 3,6 .

${ }^{8}$ Bell, pp. 220-21. Barbara Kiefer Lewalski corrects Louis Martz by stressing the distinctly Protestant quality of Herbert's inwardness in Protestant Poetics and the Seventeenth-Century Religious Lyric (Princeton, N.J.: Princeton University Press, 1979), pp. 147-49. Richard Strier takes Herbert's Protestant inwardness even further. He writes of Herbert's strong and surprisingly 
church's visible "aray" in The Temple seems more complex and more explicitly Protestant than is suggested by Walton, Walton's AngloCatholic successors, or even the apparently complacent accolades of "The British Church."

Yet these complexities and apparent contradictions fall away when we set Herbert's ecclesiastical poetry alongside Cranmer's Tudor Protestant principles, and a new consistency among the poems emerges. From this juxtaposition we also understand better why the supposedly "AngloCatholic" Herbert sounds positively "Puritan" in places. The "Old Conformity" that he inherited was itself relatively "Puritan" in rejecting institutional forms that threatened to obscure or to crowd out Reformation spiritual experience. He shared Cranmer's idea of a "legible" church, celebrated it in his verse, and sought to revive it through his pastoral manual and practice.

All reformed Christians of the sixteenth and earlier seventeenth centuries agreed that baptism and holy communion, the two sacraments retained in their churches, were the ceremonies with the most explicit warrants from Christ in the New Testament. ${ }^{9}$ However, while no quarrel arose between the Elizabethan "Old Conformists" and Puritans over the visibility or meaning of the sacraments, a sharp disagreement did emerge over the church's other accoutrements. What was the role of the external edifice-the vestments, architecture, extrabiblical rites and traditions, music - in edifying the people? Were the things retained at the Reformation an aid to worship or a stumbling block? Significantly, even in the midst of this, the foremost Elizabethan controversy, we still find remarkable agreement between the antagonists. Both parties acknowledge that the ceremonies and other externals established by the monarch in Parliament must be, in the words of the Prayer Book preface, "neither dark nor dumb ..., but ... so set forth that every man may understand what they do mean and to what use they do serve." Their "special signification" must be clear so that all "might be edified." 10

\footnotetext{
frequent impulse in his "architectural poems" toward "the internalization of religion, the replacement of external or institutional realities with internal or spiritual ones." See Strier's Love Known: Theology and Experience in George Herbert's Poetry (Chicago: University of Chicago Press, 1983), p. 146. Strier argues that at times Herbert deliberately overturns the very "Anglican" assumptions with which he has come to be identified.

${ }^{9}$ For a refutation of the view that the English Articles of Religion $(1563,1571)$ are deliberately ambiguous about communion, see J. I. Packer, "The Status of the Articles," in The Articles of the Church of England, ed. H. E. W. Turner (London: A. R. Mowbray, 1964), pp. 25-57. Packer argues that on communion and on practically every other theological point, the articles are clearly Calvinist.

${ }^{10}$ Book of Common Prayer, preface, p. 20.
} 
Thus, in condemning former British "superstition," Cranmer laments, "our excessive multitude of ceremonies was so great and many of them so dark that they did more confound and darken than declare and set forth Christ's benefits unto us." 11 Similarly, Richard Hooker's attack on superstition employs the metaphor of a "creeping, encroaching" rank growth that eventually obscures the clean, clear, and reasonable edifice of the church, resulting in "heapes of rites and customes." ${ }^{2}$ The Puritan Millenary Petition of 1603 uses this common Protestant language of simplicity and intelligibility in calling for changes in the church, now "groaning as under a common burden of human rites and ceremonies." The petition requests of the new king that "superfluous" ceremonies be eliminated, baptism better explained, communion administered only after examination and with a sermon, more "edifying" church music provided, and the "uniformity of doctrine prescribed." 13

Each of these statements-Cranmer's, Hooker's, the Petitioners'concurs essentially with Calvin's: "Shall no ceremonies then ... be given to the ignorant to help them in their inexperience? I do not say that. For I feel that this kind of help is very useful to them." Rather than rejecting ceremonies out of hand, Calvin only contends that the means used "ought to show Christ, not to hide him." Accordingly, he recommends that "to keep that means, it is necessary to keep fewness in number, ease in observance, dignity in representation, which also includes clarity." 14

All that Herbert says outside The Temple about the institutional edifice of the church aligns him, often emphatically, with this emphasis on the "legibility" of externals as signs. When Andrew Melville, like the Millenary Petitioners and most Puritans, attacks many of the human rites retained by the English Church, Herbert responds in his Latin polemic by explaining how these controverted rituals and objects teach biblical lessons. ${ }^{15}$ Although Herbert's casuistry in Musae Responsoriae is sometimes distractingly ingenious, and sometimes more sarcastic than substantive, ${ }^{16}$ the same cannot be said about chapter 35 of The Countrey Parson (1652),

11 Ibid., p. 19.

${ }^{12}$ Richard Hooker, Of the Laws of Ecclesiastical Polity, bk. 5, chap. 3, sec. 4, in The Folger Library Edition of the Works of Richard Hooker, ed. W. Speed Hill (Cambridge, Mass.: Harvard University Press, 1977).

${ }^{13}$ J. P. Kenyon, The Stuart Constitution, 1603-1688: Documents and Commentary (Cambridge: Cambridge University Press, 1966), pp. 132-33.

${ }^{14}$ John Calvin, The Institutes of the Christian Religion, trans. Ford Lewis Battles, ed. John T. McNeill (Philadelphia: Westminster Press, 1960), bk. 4, chap. 10, sec. 14.

${ }^{15}$ Works (n. 2 above); see, respectively, epigram 9, "De S. Baptismi Ritu," pp. 388-89; epigram

12, "De Purificatione post puerperium," pp. 389-90; epigram 14, "De Superpelliceo," p. 390; and epigram 26, "De annulo coniugali," p. 396.

${ }^{16}$ We should bear in mind Hutchinson's statement that this polemic is a relatively early and immature work, perhaps even having begun as precocious schoolboy versifying and completed by the ambitious young University Orator. See Works, note, pp. 587-88. 


\section{The Journal of Religion}

"The Parson's Condescending." Here a more mature and temperate Herbert invokes the same principle of doctrinal utility to defend some traditional rituals:

The Countrey Parson is a Lover of old Customes, if they be good, and harmlesse; and the rather, because Countrey people are much addicted to them.... If there be any ill in the custome, that may be severed from the good, he pares the apple, and gives them the clean to feed on. Particularly he loves Procession, and maintains it, because there are contained therein 4 manifest advantages. First, a blessing of God for the fruits of the field: Secondly, justice in the preservation of bounds: Thirdly, Charity in loving walking ... with reconciling of differences ... Fourthly, Mercy in releeving the poor.... There is much preaching in this friendliness. ${ }^{17}$

Herbert implicitly criticizes Puritan wastefulness in discarding the good with the bad and praises the edifying clarity_indeed the "preaching" power-of the good old customs. Yet Herbert's position is finally utilitarian in its condescension to the simple country folk who are "much addicted" to customs. The parson seeks the lesson or lessons to be taught, not the preservation of old ways per se. He capitalizes on the popular traditions and conforms them to his scripturally informed purposes. In other circumstances he could just as well use other customs. His stance is that of "adiaphorist" Protestantism; that is, his judgments on "indifferent things" (from the Greek adiaphora) depend entirely on what clearly edifies his flock.

Nowhere is Herbert's commitment to Cranmer's principle of "clear and special signification" clearer than in chapter 13, "The Parson's Church." 18 Beyond keeping the church building clean and repaired and maintaining the furnishings necessary for preaching, the sacraments, and charity, ${ }^{19}$ the parson concerns himself primarily with making the sanctuary "legible" in the most literal way. First, he ensures that "all the books appointed by Authority" - the Bible, The Book of Homilies, and the Prayer Book ${ }^{20}$ — be there in good condition. Second, and most strikingly, "he takes order ... that there be fit, and proper texts of Scripture every where painted, and that all the painting be grave, and reverend, not with light colours, or foolish anticks." ${ }^{11}$ The very fabric of the church should bear the holy text,

17 Ibid., pp. 283-84.

${ }^{18}$ Ibid., pp. 246-47.

19 This furniture includes "the Pulpit, and Desk, and Communion Table, and Font, . . and a Bason for Almes and ... a Poor-mans Box." See Works, p. 246.

${ }^{20}$ H. A. Wilson, ed., Constitutions and Canons Ecclesiastical, 1604 (Oxford: Clarendon Press, 1923), canon 80.

${ }^{21}$ Works, p. 246. 
thus removing any possible ambiguity about the building's purpose. In the light of Herbert's subsequent reputation, it is ironic that scripture is the only "ornament" of which Herbert speaks in this chapter. The parson's church is not a house of images, but of biblically focused devotion. Herbert intends the visible edifice to direct the worshiper's mind to heaven, but in a peculiarly Protestant way, and he cautions the parson to keep all of the externals in necessary perspective: "All this he doth, not as out of necessity, or as putting a holiness in the things, but as desiring to keep the middle way between superstition, and slovenlinesse, and as following the Apostles two great and admirable Rules in things of this nature: The first whereof is, Let all things be done decently, and in order: The second, Let all things be done to edification, I Cor. 14." 22 According to Herbert's "exact middle way," there is no holiness in the outward structures. The sancity that they have, they acquire functionally, by declaring God's holiness in His word and in His people. As Donne says in dedicating Lincoln's Inn Chapel, "These walls are holy, because the Saints of God meet here within these walls to glorifie him." ${ }^{23}$ All the better, says Herbert, if the walls themselves preach to the saints.

\section{III}

However, we cannot ignore Herbert's reputation as an edifier of actual edifices. This reputation rests largely on Walton's account of Herbert's friendship with Nicholas Ferrar, the founder of the liturgically minded community at Little Gidding, and of their cooperation in rebuilding Leighton Ecclesia in Leighton Bromswold nearby. Ferrar's often idealized community appears to have been a truly fascinating place, partly because it defied the religious classifications of that day. Indeed, the ferment of the 1620s and 1630s is well illustrated by the fact that, as we will see, Ferrar and his project were attacked both as Papist and as Puritan. ${ }^{24}$

After the Restoration, Barnabas Oley and especially Izaak Walton set about rehabilitating Ferrar, along with Herbert, as Laudian heroes. Walton, referring unabashedly to Ferrar as "Saint Nicholas," ${ }^{25}$ holds him up as a perfect example of the beautifying, retiring temperament that typified the

22 Ibid.

${ }^{23}$ The Sermons of John Donne, ed. George R. Potter and Evelyn Simpson (Berkeley: University of California Press, 1953-62), 4:364.

${ }^{24}$ For a description of Ferrar's sumptuously restored church at Little Gidding, see A. L. Maycock, Nicholas Ferrar of Little Gidding (London: SPCK, 1938), p. 133. For a page reference on Ferrar's being called a "Puritan," see n. 29 below.

${ }^{25}$ Izaak Walton, The Lives of John Donne, Sir Henry Wotton, Richard Hooker, George Herbert, and Robert Sanderson, ed. George Saintsbury, the World's Classics (London: Oxford University Press, 1962), p. 309. 


\section{The Journal of Religion}

Caroline establishment over against the fanatical, ravaging Puritans. ${ }^{26}$ The Ferrar family's loyal receptions of Charles I at Little Gidding from 1632 to $1646,{ }^{27}$ known to many modern readers through T.S. Eliot's Four Quartets, ${ }^{28} 7$ served to substantiate Walton's royalist hagiography.

However, both the Puritan and the Laudian versions of Ferrar's life and work fundamentally misrepresent their subject by overlooking his emphatically Protestant faith and his non-Arminian associations. For example, Ferrar insisted that the pope was antichrist, ${ }^{29}$ which Laud made a point of denying. ${ }^{30}$ Ferrar may have been made deacon by Laud and visited by Charles I, but he was much more substantially protected and patronized by John Williams, bishop of Lincoln and Laud's greatest adversary in the church. In fact, Ferrar's attachment to Williams led him to visit Williams in the Tower in 1636, where Laud's ill will had temporarily confined him. ${ }^{31}$ Even more significantly, a visitor to the Little Gidding church in 1634, a year after Laud's accession to Canterbury, found the sanctuary arranged in a decidedly non-Laudian manner. The communion table was not turned "altar-wise," and he saw no stained glass and no crucifix. ${ }^{32}$ What the visitor did see were four brass tablets on the east wall displaying the Lord's Prayer, the Apostles' Creed, and the Ten Commandments. ${ }^{33}$ As to the character of Ferrar and his family, a more regular visitor described them as "Orthodox, Regular, Puritan Protestants" (emphasis mine), ${ }^{34}$ while a Roman Catholic priest who once engaged Ferrar in theological controversy favorably compared the force of Ferrar's arguments to that of Martin Luther's. ${ }^{35}$ Whatever Ferrar's "Puritanism" may have been, we see that his love of ornamental and ceremonial richness does not seem to have softened his opposition to Roman Catholic sacramental doctrine or moved him to erect an edifice which he thought inconsistent with the Protestant gospel.

Herbert and Ferrar enjoyed an exceptionally warm, if mainly epistolary, friendship. The two exchanged personal counsel and various theological writings. Ferrar sent Herbert his translation of Juan de Valdes's

${ }^{26}$ Ibid., pp. 309-15.

${ }^{27}$ Maycock, pp. 128, 140, 148, 276.

${ }^{28}$ T. S. Eliot, Complete Poems and Plays, 1909-1950 (New York: Harcourt, Brace, \& World, 1952), pp. 138-45.

${ }^{29}$ Maycock, p. 239.

${ }^{30}$ The Works of the Most Reverend Father in God, William Laud, ed. W. Scott and J. Bliss (Oxford: Library of Anglo-Catholic Theology, 1848-60), 4:308-9.

${ }^{31}$ Maycock, pp. 236-39.

${ }^{32}$ Ibid., p. 138. Ferrar once said that, if he knew Mass had been said in a room of his own house, he would have that room pulled down (p. 239).

${ }^{33}$ Ibid., p. 132.

${ }^{34}$ B. Blackstone, The Ferrar Papers (Cambridge: Cambridge University Press, 1938), p. 74.

${ }^{35}$ Maycock (n. 19 above), p. 240. 
Considerations (1550), to which Herbert responded with his Briefe Notes (1632). ${ }^{36}$ It was Ferrar who after Herbert's death saw The Temple past Laud's censors and through the press at Cambridge. ${ }^{37}$ The two men seem to have trusted one another's judgment completely. Barnabas Oley writes that "they loved each other most entirely, and their very souls cleaved together most intimately, and drove a large stock of Christian intelligence together long before their deaths." ${ }^{38}$ What we have of their correspondence bears out this estimation. ${ }^{39}$

This trust seems to have extended to the reconstruction of the parish church at Leighton Bromswold, in which Herbert played an important but secondary role. ${ }^{40}$ The ideal plainness of "The Parson's Church" does not seem perfectly in accord with the sumptuousness of Little Gidding or, perhaps, of Leighton Ecclesia. The difference may be due to moneyLittle Gidding and Leighton were exceptional in enjoying the wealth of Ferrar and of Herbert's donors-or to taste since Herbert, who never saw the building at Leighton, may have deferred to Ferrar. However, regardless of the richness displayed, both men seem to have agreed that church furnishing and decoration should act like the marginalia of a judiciously illuminated manuscript: to frame and visibly express the beauty of biblical truth, yet in careful moderation so as not to obscure the "text" itself, the scripture read, preached, and even visibly displayed. Even according to Walton, Herbert on his deathbed put the edification of Leighton Ecclesia in perspective, saying that it was a "good work, if sprinkled with the blood of Christ, and not otherwise." ${ }^{11}$ To the last, Herbert was careful not to put "a holiness in the things."

During the ecclesiastical skirmishes of the $1620 \mathrm{~s}$, it was the resurgence of belief in the inherent holiness of externals, and the loss of a common appeal to "clarity and simplicity," that ominously widened the old gap between Puritans and the church establishment. As Laud and his bishops consolidated their positions in the church hierarchy they carried on controversies with the Puritans in terms different from those of their episcopal predecessors, terms which seem designed to cut off discussion entirely. Ironically, not the activist Laud but the bookish and personally mild Lancelot Andrewes, more than anyone else, provided the new rationale and its vocabulary.

${ }^{36}$ Works (n. 2 above), pp. 304-20.

${ }^{37}$ Works, pp. 546-47.

${ }^{38}$ In George Herbert, The Complete Works in Verse and Prose, 3 vols., ed. Alexander B. Grosart (London: Robson \& Sons, 1874), 3:231.

${ }^{39}$ Works, pp. 378-79.

${ }^{40}$ Amy M. Charles, A Life of George Herbert (Ithaca, N.Y.: Cornell University Press, 1977), p. 121; and Maycock, pp. 273-75.

${ }^{41}$ Walton (n. 25 above), p. 317. 


\section{The Journal of Religion}

Shortly before his death in 1626, Andrewes composed A Learned Discourse of Ceremonies Retained and used in Christian Churches, a seventyseven-page distillation of his belief that the reformed English church should maintain and restore itself in the "beauty of holiness." While this work was not printed until 1653 , it was almost certainly read in manuscript form by his clerical admirers and by Laud in particular. In any case, the book expresses views that the "Arminians" had held and defended for years. When Andrewes's argument is considered against the Tudor backdrop-Cranmer's Prayer Book preface, the homilies on ceremonies, and Hooker's Laws -its omissions are as prominent as any of its positive claims. The older language of ceremonial "clarity" and "utility" practically disappears. Virtually absent, therefore, are any claims that the "ceremonies retained" by the church contribute to the people's spiritual good.

Instead of thus shoring up Cranmer's and Hooker's traditional line of defense against Puritan charges of "popery" and "paganism," Andrewes diverges sharply by conceding-in an anthropologically fascinating twist - that many English rites do in fact derive from paganism but that this ancestry is no cause in itself for shame. He buttresses his claims for the church's debt to the pagan and Romish past with some odd, disconcerting analogies. He reasons, for example, that "if the Spaniards well may glory of their Alphonsus King of Arragon, Qui per cloacam ingressus subter Muros [who through a sewer entered under the city walls], [and] won Naples ... reasonably then cut out of former rags of the Gentiles, the glorious and fair garment of Christianity in times may be woven." 42 Such a blithe, and apparently intentional, association of the church's outward array with filth and rags seems to play directly into Puritan hands and would no doubt enrage-or perversely delight-Presbyterians like Thomas Cartwright and Andrew Melville.

Such associations also would have set Richard Hooker's teeth on edge. While Hooker writes warmly of the "naturall conveniencie" that stately and sumptuous churches and ceremonies bear to God's glory, ${ }^{43}$ he never hints at anything like Andrewes's argument based on pagan origins. Instead, as Cranmer had done, Hooker claims that some of the lawful ceremonies and externals come directly from the Jews, while others originated with the early Christian Fathers and emperors and are retained for their orderliness

\footnotetext{
42 Lancelot Andrewes, A Learned Discourse of Ceremonies Retained and used in Christian Churches (London: Charles Adams, 1653), p. 8.

${ }^{43}$ Hooker (n. 12 above), bk. 5, chap. 15, sec. 4.
} 
and teaching value. ${ }^{44}$ Hooker particularly stresses that the stately house of worship serves the believer "as a sensible help to stirre up devotion." 45

While Hooker shares his Conformist predecessor's view of external as auxiliary to devotion, he seems to differ from them over how these outward forms actually help the worshiper. Hooker's considers church architecture a sensory aid; when the senses are applied to properly meaningful objects, he believes, one's thoughts will rise to God. In contrast, the writings of the earlier Conformists focus, like Herbert, not on "sensible" richness but on the necessity and utility of the church as a well-kept meeting place where the gospel is clearly proclaimed. So we find the authorized homily on "comely adorning of Churches" (1571) approaching very closely to a "Puritan" statement, claiming that in "the cleare light of Christ Jesus ... all shadowes, figures, and significations are vtterly gone, all vaine and unprofitable ceremonies, both Jewish and Heathenish, fully abolished." Church buildings "are not set up for figures, and significations of Messias ... to come, but for other godly and necessary purposes" like preaching, prayer, and communion. The "Church or Temple" is called "holy, yet not of it self," but because of these "godly and necessary" activities. ${ }^{46}$

Like Cranmer in his Prayer Book preface, and unlike Hooker, the homilist foregrounds the function of the holy place, stressing what has been "cut away and clean rejected" by the Reformation, and why. He anticipates Herbert, exhorting his readers to keep their sanctuaries well repaired, "honourably adorned, . . cleane and sweete, to the comfort of the people," and inveighing against "phantasticall adorning and decking." 47

Horton Davies has contrasted this quasi-Puritan "functionalism" with the architectural "numinosity" advocated by Andrewes, Laud, and their disciples. Just how far both Hooker and his predecessors would diverge from the Arminian sacralization of architecture appears in Andrewes's prayer consecrating Jesus Chapel, Peartree, Southhampton, in 1620. To Andrewes, the building is no mere "sensible help," but fully God's "habitacion" since "above all, in this place, the very gate of heaven upon earth, ... [we meet] to do the work of heaven" at the altar. ${ }^{48}$ For in Laud's words, the altar is "greater than the pulpit; ... there it is 'This is My Body'; but in the pulpit it is at most but ... This is My Word.' And a greater reverence no

${ }^{44}$ Ibid., bk. 5, chaps. 11, 12.

${ }^{45}$ Ibid., bk. 5, chap. 16, sec. 2.

${ }^{46}$ Certaine Sermons or Homilies Appointed to be Read in Churches in the Time of Elizabeth I (15471571). A Facsimile Reproduction of the Edition of 1623 (Gainesville, Fla.: Scholars' Facsimiles \& Reprints, 1968), 2:78-79.

${ }^{47}$ Ibid., pp. 77, 80.

${ }^{48}$ J. W. Legg, English Orders for Consecrating Churches in the Seventeenth Century (London: Henry Bradshaw Society, 1911), 41:57. 


\section{The Journal of Religion}

doubt is due to the Body than to the Word of our Lord."49 Thus, as Davies argues, from Hooker to Laud there is a de-emphasis of verbal edification, accompanied by an increase in the claims made for the divine preeminence of the physical edifice. To the Laudians, churches are not merely "convenient" or "didactically valuable" or only places where "angels joins with humans in worship"; they are the dwelling places of Christ's "Real Presence" in the consecrated bread and wine. The place, and its furnishings, become holy in themselves-indeed, "numinous." 50

Much as the earlier Conformists sound surprisingly "Puritan" in comparison to the Arminians, so most Puritans were not as iconoclastic as has often been thought. As already noted, Calvin held some ceremonies to be useful "to the ignorant to help them in their inexperience," as long as "the means ... show Christ, not ... hide him." ${ }^{51}$ For this reason, as Kilian McDonnell writes, Calvin chided John Knox "for being unbending on a matter of ritual, unbending even to the point of distrubing a refugee congregation with Anglican ritualistic leanings." 52 Yet even Knox's own Booke of Discipline (1560) orders that all the dilapidated kirks of Scotland be quickly repaired "with such preparation within, as appertaineth as well to the Majestie of God, as unto the ease and commodity of the people lest the word of God, and the ministration of the Sacraments by unseemlinesse of the place come in contempt" (emphasis mine).$^{53}$ Even for the Scots presbyterians, ecclesiastical architecture must in some way fit God's grandeur.

As to English Puritan attitudes toward liturgy and ceremony, Patrick Collinson writes that under Elizabeth they were at least "willing to enclose their worship in a fixed and invariable order." Collinson cites George Gifford, "the deprived vicar of Maldon and no moderate," as a defender of set prayers and liturgies against the separatist John Greenwood. Gifford speaks for the Puritan mainstream (in Collinson) when he writes that "About ... commanding a prescript form of prayer to be used, our Church doth agree with all godly churches, yea the reformed churches have and do practice the same.... There would sundry inconveniences grow for want of a liturgy, or prescript form of public prayers." 54 Thus

${ }^{49}$ Laud (n. 25 above), 6:56-57.

${ }^{50}$ Horton Davies, Worship and Theology in England (Princeton, N.J.: Princeton University Press, 1975), 2:17.

${ }^{51}$ Calvin (n. 14 above), bk. 4, chap. 10, sec. 4.

${ }^{52}$ Kilian McDonnell, O.S.B., John Calvin, the Church, and the Eucharist (Princeton, N.J.: Princeton University Press, 1967), p. 129; referring to John Knox, Works, ed. David Laing (Edinburgh: Wodrow Society, 1895), 4:51-52.

${ }^{53}$ [John Knox], The First and Second Booke of Discipline (Edinburgh, 1560; reprint, London, 1641), p. 71.

${ }^{54}$ George Gifford, quoted by Patrick Collinson in John Greenwood, The Writings of John Greenwood, 1587-1590, ed. Leland H. Carlson, published for the Sir Halley Stewart Trust (London: Allen \& Unwin, 1962), pp. 57-58, 75. 
while many Puritan ministers omitted certain collects and ceremonies in their use of the Prayer Book, they still chose to use it rather than the plainer (and forbidden) Puritan alternative, the Geneva Book, so that "there might be as much conformity as might be outwardly." 55

So we see that the Elizabethan Conformists and Puritans agreed that their church needed a "fit aray" but disagreed over which externals, or how many, best suited God's glory and the clear preaching of the gospel. As in their other disputes over "things indifferent," the controversy reduces to two conflicting views of scriptural authority. For all their theological common ground, they parted company over whether the church should establish and enforce only those things clearly commanded in the Bible-the Puritan position-or whether the church's prerogative extended to mandating things allowed by, or not contrary to, the Biblethe Conformist position. ${ }^{56}$ Yet they share far more in common with each other than with Laud's renewal of devotion to holy places.

I turn now to consider the relationship of The Temple, and particularly the lyrics of "The Church," to the externals of worship. Herbert, as both pastor and poet, is committed to edifying the congregation and the reader within the structures of the British church, so he praises them as necessary, fit, and beautiful. Yet his overall thrust is internal, toward building the altar and temple in the heart. This internalizing impulse carries through poem after poem, so much so that he apparently is responding to the attitude, if not to the claim, that mere observance of the church's outward order can substitute for a deeply felt inward life. Thus the church edifice is for Herbert a kind of three-dimensional emblem book "to stir up the dull mind of man" toward God. Yet when the sign is set in the scales against the spiritual reality that it signifies, Herbert values "all this pomp and state" as less than "one good grone."

When we consider each of Herbert's many poems that touch directly or indirectly on the church's sacraments, architecture, vestments, ceremonies, liturgy, and calendar, we discover that these entities are seldom literally present to the poem's speaker, and, even when literally present to his senses, they lead him to specifically Protestant meditations and lessons. However, most of Herbert's poetic references to ecclesiatical externals are clearly metaphorical from the beginning, so that, while they reveal a

\footnotetext{
${ }^{55}$ Patrick Collinson, Elizabethan Puritan Movement (Berkeley: University of California Press, 1967), pp. 363, 361, respectively.

56 John S. Coolidge, The Pauline Renaissance in England: Puritanism and the Bible (Berkeley: University of California Press, 1970), pp. 10-11.
} 


\section{The Journal of Religion}

mind favorably disposed to liturgical orderliness, they do not provide models for direct meditation on places and physical objects. Besides these straightforwardly literal or clearly metaphorical references to the visíble edifice, there is a third way in which Herbert typically treats outward things, where he deliberately misleads us with a "redefining" or "vanishing" motif. In this kind of poem, the speaker either considers a literal entity - a feast day, Christ's Passion, Solomon's temple-only to redefine or devalue it, or he causes the "real" object to vanish by the poem's end. We are left to see the object in retrospect as an emblem of, rather than a numinous aid to, devotion.

The great exception to such diminishing treatments of externals would seem to be "The British Church"; Herbert's serene satisfaction here with his "dearest Mother" is all the more notable when compared with Donne's restless questioning in Holy Sonnet 18, "Show me dear Christ, thy spouse, so bright and clear." 57 Donne's poem, probably written in 1620 , reveals his doubts about the status not only of the continental Catholic and Protestant churches, but of his own as well. ${ }^{58}$ In contrast, Herbert warmly praises England's unique "middle way," the "mean" that all others miss. However, we should note carefully just what Herbert is, and what he is not, praising. Many have been found in these lines a defense of Laudian "finery." Yet a closer look at the first two stanzas reveals that the church's "fineness" is not in her "aray" - presumably the liturgical and material externals-but in her "aspect," her "face," where living personality and rationality are most clearly displayed. Her "lineaments and hue" may be "perfect," her array "fit," but their perfection does not necessarily imply Hooker's, or even Ferrar's, "sumptuousnesse." The church's array is "fit" because it does not distract from the "beautie" of her "face." Ecclesiastical "nakedness"-the Genevan "she" who "nothing wears"-is also to be avoided, for it distracts in an opposite fashion from the church's "fine aspect."

Furthermore, although Herbert portrays the British way as a mean between extremes, he does not portray these extremes as equally dangerous. The painted "wanton" of Rome, with her excessive ornamentation, is a continually seductive threat who "allureth all" to idolatrous worship at her "painted shrines." In contrast, the nakedness of Geneva "in the valley" is not seductive, but unattractive, and in Herbert's view somewhat absurd. Geneva can be faulted for a strange and inappropriate "shyness" rather than "pride." Hooker had noted that, in the days of primitive

\footnotetext{
${ }^{57}$ John Donne, The Complete English Poems, ed. A. J. Smith (Harmondsworth: Penguin, 1971), p. 316.

${ }^{58}$ Because of the poem's searching theme, some scholars have placed it before Donne's ordination in 1615; however, the particular historical references seem to place it in 1620. See ibid., notes, pp. 635-36.
} 
Christianity, before the advent of Christian kings, the church's plainness "was suteable unto the nakedness of Jesus Christ and the simplicitie of his Gospel." ${ }^{59}$ Hooker makes no similar allowance for Roman excess. Likewise Herbert, in walking his via media, is less harsh on Protestant Geneva than on papal Rome.60

So the traditional reading - that "The British Church" endorses the "beautifying" policies of emerging Laudianism-cannot be maintained. Even if we disregard the evidence of Herbert's statements about the relatively plain "Parson's Church," this lyric itself will not bear such a reading. Herbert gives no direct, literal referent for the "fit" - not "fine" - "aray" that he celebrates. We have no warrant to assume that this array includes the railed altars, additional stained glass, and statuary that Laud instituted.

Beyond this poem's appreciation of the church's modesty and decency of dress, such externals very seldom stir the senses of The Temple's poetic speakers as direct aids to devotion. Only "Church-monuments" among all The Temple's lyrics even suggests the kind of sensory "numinosity" that was to become the model for later "Anglican" meditation-such objects usually being liturgical or physical entities not specified in Scripture. This "Anglican" paradigm is adumbrated in Hooker's recommendation of "sensible help[s] to stirre up devotion," developed in such Arminian works as John Cosin's Private Devotions (1626) and given its fullest expression two hundred years later in John Keble's Christian Year (1827).

However, even "Church-monuments" is problematic as "Anglican" meditation. While the poem's speaker seems to focus visually on the more elaborate indoor genealogical memorial of "Jeat and Marble" - suggested by the "dusty heraldrie and lines" and the repeated play on "birth" and "true descent"- he combines these "sensible" qualities with those of the more common outdoor headstone-suggested by the language of grave "heaps," the windy "blast of death's incessant motion," and even the poem's monolithic shape-there are no stanza breaks in the Williams or Bodleian manuscripts. ${ }^{61}$ This mental blurring of two distinct visual forms makes it difficult to imagine the monument as a discrete object, yet adds to the monument's power as a memento mori, a sign of impending death on which we must all read our own names.

Indeed, the monument's lessons, while not uniquely Protestant, are all clearly biblical. The imagery of dusty headstones and grave heaps draws the speaker to echo Gen. 3:19 ("dust thou art, and unto dust shalt thou return") and Psalm 39:4 ("Lord, make me know mine end, and the meas-

\footnotetext{
${ }^{59}$ Hooker (n. 12 above), bk. 5, chap. 15, sec. 1.

${ }^{60}$ See Richard Strier, "History, Criticism, and Herbert: A Polemical Note," Papers on Language and Literature 17 (1981): 347-52.

${ }^{61}$ Works (n. 2 above), see Hutchinson's notes, pp. 498-99.
} 


\section{The Journal of Religion}

ure of my days what it is; that I may know how frail I am"). Reminded of his "true descent," he exhorts his flesh to mortify its lusts and thus "fit thy self against thy fall." Correspondingly, the image of heraldic lineages suggests the irony of celebrating one's family name in a place intended to show that such names are inconsequential. ${ }^{62}$ Thus the church monuments, and perhaps even the churches themselves, teach their lessons not by their numinous "sumptuousness" or their intended permanence, but by their ironic and inevitable decay. In the state of mind expressed by this poem, Herbert would behold Laud's grandest sanctuary and think, very probably, of the biblical vanitas vanitatis.

In fact, of all Herbert's lyrics, only "The Knell” works as "Anglican" meditation. Like Donne in the Devotions upon Emergent Occasions, ${ }^{63}$ Herbert hears the tolling of the plague-time bell and is led by it to contemplate the impending physical disease as a spiritual remedy since it draws his mind to impending death. However, while "The Knell" appears in the Williams manuscript, Herbert chose to exclude it from the final version of The Temple.

None of Herbert's other poems that deal literally with the church's outward forms can be seen as distinctly "Anglican" since all of these refer to rites and events specified in the New Testament and that all but the most extreme Puritan sects treated as parts of the church's necessary order. The " $\mathrm{H}$. Baptisme" and communion poems, especially "The H. Communion" and "The Banquet," celebrate Holy Spirit's use of the outward sign to seal his promises and lift the believer to experience heavenly glories. Similarly, "church-musick" raises the worshiper in ecstasy to "heavens doore" as Saint Paul recommends in Col. 3:16. "Sunday," "Easter," and "Christmas" meditate on scriptural events or holy days in terms that Puritans could, and often did, share. "Sunday" in particular would appeal to sabbatarian sensibilities since it stresses that the Lord's Day is for rest and worship, not for the "burden" or the "vanities" of the "worky-daies" — much in contrast to Laud's controversial defense of Sunday "sports," dances, and church-ales. ${ }^{64}$

While Herbert's literal references to the church's outward forms and structures are surprisingly few, The Temple as a whole is permeated with ecclesiastical and liturgical language. However, these ecclesiastical references are, from the beginning, clearly metaphorical or otherwise internalized, representing spiritual realities that come to exist fundamentally within the believer. Some of these "internalizing" lyrics display a unique

\footnotetext{
${ }^{62} \mathrm{I}$ am indebted to Cristina Malcolmson for this insight.

${ }^{63}$ John Donne, Devotions upon Emergent Occasions (Ann Arbor: University of Michigan Press, 1959), pp. 108-9.

${ }^{64}$ Such activities, strongly favored by Charles and Laud and opposed by the Puritans as profaning the Sabbath, included church-ales, Whitsun-ales, Maypole and Morris dancing, and "leaping and vaulting." See Tindal Hart, The Country Clergy, 1558-1660 (London: Phoenix House, 1958), pp. 72-73, 96-97.
} 
relationship between the title and the body of the poem, a relationship like that exhibited by "The Pulley," "The Collar," and "The Holdfast" with their respective titles. In such cases, the title object never appears within the poem itself, even as a metaphor, yet the title is the key to the poem's unity. After reading the entire poem we return to the title and relate certain key words, images, and motifs to the speaker's inner state, retrospectively discovering the purpose of that governing image or action.

For example, in "Trinitie Sunday" the holy day is not named outside of the title, nor are the particular Persons of the Trinity named anywhere. However, the overall three-line, three-stanza pattern is implicitly "trinitarian," as is the application to the self of God's saving work:

Lord, who hast form'd me out of mud, And hast redeem'd me through thy bloud, And sanctifi'd me to do good;

Purge all my sinnes done heretofore:

For I confesse my heavie score,

And I will strive to sinne no more.

Enrich my heart, mouth, hands in me,

With faith, with hope, with charitie;

That I may runne, rise, rest with thee. ${ }^{65}$

Each Person forms a particular function: God the Father as creator "forms" and "purges," God the Son "redeems" and as priest hears "confession," and God the Holy Spirit "sanctifies" by removing the tendency to $\sin$. The three triads of the third stanza complete the pattern.

Similarly, Herbert's famous "shaped" poem "Easter-wings" mentions Easter nowhere but in the title. The "daye" referred to could and should be every day, according to the lesson of "Easter":

Can there be any day but this,

Though many sunnes to shine endeavor?

We count three hundred, but we misse:

There is but one, and that one ever. ${ }^{66}$

The believer rises constantly with Christ's Resurrection, and the missing reference to the canonical Easter Sunday in "Easter-wings" reminds us that the Resurrection numbers all our days. ${ }^{67}$ Likewise, the title of "The Crosse" might lead us to expect a meditation on "the bloudie crosse of my deare

65 Works, p. 68.

${ }^{66}$ Ibid., pp. 42-43.

${ }^{67}$ See Strier's account of Herbert's challenge to our reasonable numerical expectations in "Easter" in Love Known (n. 8 above), pp. 59-60. 


\section{The Journal of Religion}

Lord," as in "Conscience." Instead we find an implicit, extended pun on the "crosse-biassing"- the spiritual frustration-of which Herbert complains in "Affliction" (I). Herbert's elimination of a literal crucifix is consistent with the Protestant rejection of ascetic mortification. It is the speaker's proud will, not his prison house of flesh, that causes his misery.

Analogously, the title of "Confession" gives its lyric an ironic twist since this heading introduces, not a liturgical confession, but a complaining individual Christian's view of suffering as divine torture, calculated to extract an unwilling admission of guilt:

No scrue, no piercer can

Into a piece of timber work and winde,

As Gods afflictions into man,

When he a torture hath design'd. ${ }^{68}$

Furthermore, the poem's final, nonironic confession of real "faults and sinnes" - sins like the ingratitude of the earlier lines-is expressed in colloquial and arrestingly personal terms not borrowed from any collect. ${ }^{69}$

I challenge here the brightest day,

The clearest diamond: let them do their best,

They shall be thick and cloudie to my breast.

Confession and cleansing take place entirely within the penitent. There is no priest here to pronounce absolution.

"Mattens" and "Even-song" display Herbert's internalizing tendency by personalizing the public Prayer Book collects for morning and evening prayer. While the emphasis in "Mattens" on seeing God in his creation echoes the Benedicite omnia opera Domini Domino of morning prayer, ${ }^{70}$ the emphasis in "Even-song" is notably different from that of the collect for evening prayer. ${ }^{71}$ All of the evening collects mention the peril of the night, especially the third, which calls on God to "Lighten our darkness ... and by thy great mercy defend us from all perils and dangers." In contrast, "Even-song" celebrates the night's sheltering, beautiful tranquillity: it is the "ebony box" where "Thou dost inclose us," "th'harbor" from the day's "gale," the "arbour" and the "grove" of restful shade. ${ }^{72}$ Conversely, the "Euen-song" of the Williams manuscript, which repeats the Prayer Book plea for protection, is an entirely different poem that Herbert excludes from the final version of "The Church." Moreover, in none of these three poems-"Mattens," "Even-song," or "Euen-song"-

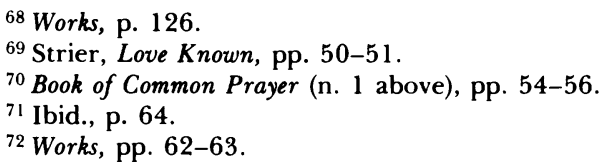


does Herbert speak to, or for, or with a congregation but, rather, as an individual "I" to the divine "Thou." The distinctly liturgical quality of common prayer that the titles lead us to expect is replaced in the lyrics by a single personal voice.

Distinct from these lyrics, which bear only a retrospective, and sometimes ironic, relationship to their metaphorical titles, are those tied together by an extended ecclesiastical analogy, introduced in the title and explicitly invoked more or less throughout the poem. From the beginning each of these lyrics figuratively uses outward objects to express inward realities. Thus "The Windows," one of Herbert's most affecting architectural poems, is not about how stained-glass windows inspire devotion but about how a preacher is a window. In and of himself the preacher, like all mortals, is only a "brittle crazie glass" which "shows watrish, bleak, \& thin"; but through God's grace Christ's life will be "annealed" within his life, so that "Doctrine and life, colours and light, in one" will "bring / A strong regard and aw" from his hearers. Another architectural lyric, "Church-lock and key," works as allegory. The "church" to which the speaker wishes admittance signifies God's attentive presence, his "eares"; the "lock" that keeps the speaker out is "my sinne"; and the "key" is Christ's shed blood, which wins a hearing from God for the sinner. It means much for "The Church" as a whole cycle of poems that to be inside "the church" means to be heard by God. The space of the sanctuary becomes a metaphor for divine favor. ${ }^{73}$

Herbert's most famous architectural poem, his hieroglyph, ${ }^{74}$ "The Altar," is explicitly metaphorical and internalized from the first, being "made of a heart, and cemented with teares." ${ }^{75}$ Herbert's analogy here is not to a church communion table turned "altar-wise" in Laudian fashion but to the Old Testament sacrifical altar made of stones not touched by a "workman's tool." 76 This ancient altar Herbert likens to his heart, which is "such a stone, / As nothing but / Thy pow'r can cut."77 Thus Herbert points to the finished sacrifice of Christ and, at the same time, to the now wholly inward sacrifice of the believer's broken and contrite heart. This prominently metaphorical use of "altar," a politically explosive term in the 1630 s, and the absence of a contemporary literal "altar" cut against Laud's and even Hooker's exaltation of visible, physical sumptuousness to focus instead on the hidden core of the self.

\footnotetext{
${ }^{73}$ Works, p. 67 (“Windows”), p. 66 (“Church-lock”).

${ }^{74}$ See Joseph Summers, George Herbert: His Religion and Art (Cambridge, Mass.: Harvard University Press, 1954), pp. 123-46, for a discussion of such "hieroglyphs" as "complete visual emblems."

${ }^{75}$ Works, p. 26.

${ }^{76}$ See Deut. 27:5-7.

77 Works, p. 26.
} 


\section{The Journal of Religion}

A third kind of ecclesiastical poem not only counters Hooker and Laud but also seems to place Herbert on the borderline between the "Old Conformist" and Puritan positions. In these poems, Herbert either redefines the external entity in terms more strongly Protestant than he had led us to expect, or he simply makes the literal object disappear. As Ilona Bell has argued, the "Passion cycle" that begins "The Church" shows Herbert's commitment "to the Reformation and Protestantism, to reform and protest" by turning the forms of ascetic devotional poetry back against themselves. "Much as Sidney and Donne raided and exploded the Petrarchan conventions," writes Bell, "Herbert used and doomed the familiar images, postures, and goals of Catholic meditation." 78

Other lyrics in this category similarly redefine Catholic externals in Protestant terms. "Lent" initially celebrates and recommends a certain degree of physical fasting during the Lenten season, yet in the final stanza Herbert seems to undercut this practice by stressing the primary importance of internal "fasting" from sin, externally demonstrated by literally feasting the poor who come to one's door. "To all Angels and Saints" apparently begins by invoking the angels, saints, and the Blessed Virgin but ends by rejecting such an invocation in a determination to do only what God clearly commands. "The Priesthood" makes ordination to a sacerdotal office its initial topic, but at the poem's end replaces the external forms of ordination, and the human bishop, with a prayer for personal, direct calling from God. In addition to these poems, "Whitsunday" observes the canonical holy day of Pentecost but does so by criticizing the present spiritual state of the British church, calling on God to restore truly Pentecostal fire and inner joy to its preachers, including the speaker himself. ${ }^{79}$ Similarly, "Antiphon" (I) could be set to music and sung as an actual antiphon, but its final lines emphasize inner singing, for "above all, the heart / Must bear the longest part." 80

In contrast to Herbert's Protestantizing devotional strategies, the Private Devotions (1626) of Laudian bishop John Cosin recommend an emotional reenactment of the Passion in terms that seem to parallel Loyola's Spiritual Exercises. Cosin writes that "about the Time of His Passion we should have a sympathie, a com-passion and a fellow-feeling with him, being made conformable unto him herein by the exercises of Repentence, which are The Passion of every Christian, whereby he dyeth unto sinne; and that the solemne Joy of our Redemption should be put off till EASTER

${ }^{78}$ Bell (n. 5 above), pp. 222, 237. See especially Bell's discussion of how the initial Passion cycle of The Temple ultimately rejects any attempt at vivid, present-tense evocation of Christ's sufferings.

${ }^{79}$ The implicit personal reference here is strengthened by the fact that Herbert's prebendary at Leighton Bromswold required him to preach a Whitsunday sermon each year. See Charles (n. 40 above), pp. 121-22.

${ }^{80}$ Works, p. 53. 


\section{Herbert and the Externals of Worship}

DAY, the day of his Resurrection." 81 Cosin's belief that Christians should conform their feelings to the seasons of the church, shutting out joy every Lent until Easter, differs profoundly from Herbert's already-noted affirmation in "Easter" that resurrection joy should fill every day of the calendar. The gap between "Arminianism" and Herbert's "Old Conformity" is wide, not only in a doctrinal sense, but also in devotional sensibility.

"Sion" is the most representative of Herbert's "redefining" or "Protestantizing" group because it is his most global statement preferring inwardness to externality; thus it is his greatest departure not only from Rome and from Laud but also from Hooker. The first stanza begins its apparent celebration of Solomon's glorious temple and what Hooker would have called its "naturall conveniencie" to the grandeur of God: "Lord, with what glorie wast thou served of old, / When Solomons temple stood and flourished!" He praises the "things ... of purest gold," and the wood "embellished / With flowers and carvings, mysticall and rare"-mystical carvings, Herbert surely believed, that foreshadowed Christ's coming glory. However, the last line of this stanza introduces a worrisome note. If all of this visible grandeur "show'd the builders, crav'd the seeers [sic] care," then God himself may be overlooked in the exchange. The mystical carvings might even hide Christ now, in this age of full revelation. ${ }^{82}$

Calvin and his Puritan disciples protested against such a danger. In their view, as Kilian McDonnell explains, such grandeur made it "difficult for a man to meet his God and speak with him apart from ... the sanctuary externality of the official church. The ... splendor to which the layman contributed only the obedient passivity of awe ... had rendered the believer's contact with God too churchy." ${ }^{83}$ In short, the externals could crowd out the living God. Herbert expresses similar feelings in the next three stanzas when he insists that God's "aim" was, and is, not "all this glorie, all this pomp and state" of "Architecture," but the spiritual "frame and fabrick ... within" the individual believer. It is here that the sinful constructions of the heart are pulled down and here that God lays up his greatest treasure- "one good grone" of real repentance. It is precisely Herbert's quest for spiritual "wings" that leads him to devalue the "brasse and stones" of grand sacred architecture. In his own shockingly strong terms, these "heavie things" are "Tombes for the dead." Instead of being spiritually "convenient," they are grossly, perhaps fatally, cumbersome, like biblical millstones around the neck. In the age of grace, God's favored building site is the heart. ${ }^{84}$

${ }^{81}$ John Cosin, A Collection of Private Devotions, ed. P. G. Stanwood (Oxford: Clarendon Press, 1967), p. 199.

82 Works, p. 66.

${ }^{83}$ McDonnell (n. 52 above), p. 112.

${ }^{84}$ Works, p. 66. 


\section{The Journal of Religion}

The last and most radical of these "redefining" or "Protestantizing" lyrics are those with a deliberately misleading "vanishing motif." Richard Strier has shown how Herbert displays this "sleight of hand" in "The Church-floore" and "Aaron," in which literal structures or objects-a church's paving stones, a priest's robes-seem present to the speaker at first but, in retrospect, turn out to have been metaphorical all along. ${ }^{85}$ "A true Hymne" presents itself as formally fit for a musical setting, yet its lyrical content makes it virtually impossible as an actual congregational hymn. The poem begins with an exuberantly hymnic exclamation-"My joy, my life, my crown!" - but immediatly takes a perplexing turn as the "hymnist" asserts that this one line may be a true hymn by itself, and that lyric "art" may be unnecessary for real devotion:

My joy, my life, my crown!

My heart was meaning all the day,

Somewhat it fain would say:

And still it runneth mutt'ring up and down

With onely this, My joy, my life, my crown.

Yet slight not these few words:

If truly said, they may take the part

Among the best in art.

The finenesse which a hymne or psalme affords

Is, when the soul unto the lines accords. ${ }^{86}$

Such a self-reflexive lyric, with its deliberately unmusical lines ("And still it runneth mutt'ring up and down") is designed not to be sung but to be stumbled on, considered and reconsidered. It works to prevent the antiphonal repetition of which the Puritans often complained ${ }^{87}$ and to illustrate Herbert's stated point: that the true "art" or "finenesse" of a hymn is produced only in the heart of a devoted worshiper, whose "soul unto the lines accords," whose heart "rymes" with the words. "If th'heart be moved," then even if the verse, like Herbert's here, is "somewhat scant, / God doth supplie the want." ${ }^{88}$ A "true hymn" need to be no formal hymn at all.

This replacement of outer objects with inner experience is not confined to individual lyrics. Indeed, the entire Temple, and "The Church-porch" and "The Church" contained within it, can perform this "vanishing act" on the reader who comes to the text expecting to find a collection of analogical meditations on a visibly numinous edifice. When we have come

\footnotetext{
${ }^{85}$ See the discussion of Herbert's similar sleight of hand in "The Church-floore" and "Aaron" in Strier, Love Known (n. 8 above), pp. 127-34, 149-50.

${ }^{86}$ Works, p. 168.

${ }^{87}$ Collinson (n. 55 above), p. 359.

${ }^{88}$ Works, p. 168.
} 


\section{Herbert and the Externals of Worship}

through "The Church-porch" to the "Superliminare" and we read there the invitation to enter and "taste / The churches mysticall repast," we could easily assume that the Mass is meant ${ }^{89}$ Indeed, the sight of "The Altar" and "The Sacrifice" beyond the "door" seems to confirm such expectations of a reenacted sin offering. However, as we have noted, a close and responsive reading of these two poems and the "Passion cycle" that they begin should overthrow our first impressions.

Still, the materiality of "The Church's" edifice seems to reassert itself in the liturgical and architectural titles grouped between "Mattens" and "The Windows," 90 in the "calendar poems" interspersed throughout and in the penultimate eucharistic poems that lead up to the final communion of "Love" (III). However, even if we have carried our misconception of Herbert's intent so far, the final line of this last lyric should demonstrate to us that he has been speaking all along of "the temple" within the believer. The communion of "Love" (III), like the entire "mysticall repast" of "The Church," cannot refer to the literal sacrament ordered by the Prayer Book, for if it did, Herbert would never "sit and eat" (emphasis mine). ${ }^{91}$ In The Countrey Parson he rejects such a eucharistic posture, writing that at the sacrament "hee that kneels, confesseth himself an unworthy [guest]," while "hee that sits, or lies, puts up to an Apostle." ${ }^{2}$ Ironically, it is because of Herbert's known loyalty to the Church of England's external forms that "Love" (III), like the whole of The Temple, must refer to the Christian's internal, eternal fellowship with the risen Christ. ${ }^{93}$

If, for Herbert, externality and inwardness are so ironically yet profoundly related, can they be reconciled? Reconciliation might at first seem difficult, given the apparently stark contrast that we have observed between his appreciation and devaluation of outward forms. Herbert deals with this problem of ornament obscuring rather than displaying truth in "Jordan" (II), where he retrospectively chides himself for having fallen prey to the temptation of overembellishing his expressions of devo-

${ }^{89}$ Ibid., p. 25.

${ }^{90}$ This group (in Works [n. 2 above], pp. 62-68) consists of "Mattens, "Even-song," "Churchmonuments," "Church-musick," "Church-lock and key," "The Church-floore," and "The Windows."

${ }^{91}$ See the discussion of this point in Strier, Love Known, p. 78, n. 41.

${ }^{92}$ Works, p. 259.

${ }^{93}$ The blank-page break in the Bodleian manuscript between "The Church" and "The Church Militant," along with Herbert's inscription of "Finis" at the end of "Love" (III), suggests that he considered "The Church Militant" a work separate from The Temple. 


\section{The Journal of Religion}

tion. His was a pious mistake, Herbert says; he was so taken with the "lustre" of his first spiritual experiences that he sought to "deck" them in the richness appropriate to their glory.

There is an ironic similarity between Herbert's efforts to "clothe the sun" and Hooker's account of the church's growth in visible glory. As we have noted, Hooker concedes that in the days of primitive Christianity the church's poor surroundings were "suteable unto the nakedness of Jesus Christ and the simplicitie of his Gospell." However, he continues, "Touchinge God him selfe, hath he anie where revealed that it is his delight to dwell beggarlie? and that he taketh no pleasure to be worshipped savinge onelie in poore cotages? Even then was the Lord as acceptiblie honored of his people as ever, when the stateliest places and thinges in the world were sought out to adorne his temple. This most suteable decent and fit for the greatnes of Jesus Christ, for the sublimitie of his Gospell."94 According to Hooker, "all this glorie, all this pompe and state" was indeed God's aim. The Lord will tolerate "beggarlie" accommodations "when the state of the Church is poore" but expects fitting outward splendor when he "hath inritched it with plentie." 95 To everything there is a season, says Hooker, and under godly monarchs the season is one of visible glory for the church. For a nation to do less for God when it has the means argues serious irreverence, even blasphemy. Nothing should seem too rich to clothe the sublimity of Christ's gospel.

That Hooker speaks in terms almost identical to those of Herbert's pious error in "Jordan" (II) reveals their profound difference in sensibility, and perhaps in actual principle, over the place of ornament in worship. Like Herbert's earlier self, Hooker proposes to measure devotion by the amount and degree of "trim invention" decking the outward expressions of devotion. For Hooker, the present glorious ascendency of Christian rulers defines "fitness" as "fineness," even grandeur. However, for Herbert the church's "fit aray" is, as we have seen, that which does not distract from the "fine aspect" of the church's truth and which does not "show the builders, crave the seeers care" at the expense of the spiritual "frame and fabrick ... within." 96

In Herbert's view, Hooker's pious externalism might lead to the consuming "bustle" that conscientiously_and confusingly_embellishes the "plain intention" of reformed worship. Like the blunt "friend" of "Jordan" (II) God would have his worshipers "copie out onely that" which clearly expresses the personal, inner "sweetnesse" of Christ's love. All other embellishment-the "quaint" traditions and ceremonial "in-

\footnotetext{
${ }^{94}$ Hooker (n. 12 above), bk. 5, chap. 15, secs. 2-3.

${ }^{95}$ Ibid.

${ }^{96}$ Works, p. 106.
} 


\section{Herbert and the Externals of Worship}

vention" not grounded in this personal love-is distractingly "long pretence" that makes the message unintelligible. Marginal illumination must truly illuminate, not overgrow, the text. Those baptized in the spiritual "Jordan" ought not to repeat such a mistake.

It is no mere coincidence that Herbert's cautions concerning poetic and ecclesiastical ornamentation should dovetail so neatly. In both cases it is the legibility of the plain and powerful gospel message that concerns him. While God is the ultimate "reader" both of his lyrics and of the church's "notable and special significations," both "texts" are meant immediately for finite and fallible human readers. Such readers need a plain and comprehensible transmission of the truth if they are to be edified.

Given this principle of legibility, it seems not only possible but surprisingly uncomplicated to harmonize "The British Church" with "Sion" and with the internalizing impetus of the entire Temple. Whether any particular poem praises or denigrates externals depends on the speaker's rhetorical stance in response to a perceived threat. In the celebratory "British Church," Herbert answers not only Romanist but also Puritan complaints by arguing that English moderation in externals fitly displays her essential saving message by preventing the distractions of either excess. However, when the externals of worship are treated as anything more than a decent garment or an edifying text - when, in other words, they are emphasized at the expense of the inner life that they signify, or, worse yet, are equated with it - then Herbert puts them in perspective. He waves away the brass and stone, the robes, rites, seasons, days, collects, hymns, even (perhaps especially) his own poems as the mere figures and shadows that he has always believed them to be.

For Herbert, the fault or virtue lies not in the externals themselves, but in the ignorance or understanding that people bring to them. It is only after the worshiper has followed Herbert in dismissing the church's outward shadows that he can use them in devotion with a clear conscience and with joy. Thus Herbert shared the "Old Conformist" idea of a reformed British church: to purify the church's forms meant to clarify them. Herbert's inclusiveness distinguished him from the Puritans, with whom he otherwise shared so much. The fact that The Temple is so devoted to "clarifying" these forms by making them disappear suggests that Herbert saw a greater spiritual danger in Lavel's reviving devotion to "brasse and stones." For Herbert the "transparency" of the visible church is not so much that of plain glass - which, after all, might merely show "watrish, bleak, and thin" 97 - but of a plain text or a clear sermon, translucent to the mind, and powerfully moving the heart.

${ }^{97}$ Ibid., p. 67. 